\title{
Satellite tracking and stable isotope analysis highlight differential recruitment among foraging areas in green turtles
}

\author{
Phil J. Bradshaw ${ }^{1}$, Annette C. Broderick ${ }^{1}$, Carlos Carreras ${ }^{1,2}{ }^{,}$Richard Inger $^{1,3}$, \\ Wayne Fuller ${ }^{1,4}$, Robin Snape ${ }^{1}$, Kimberley L. Stokes ${ }^{1}$, Brendan J. Godley ${ }^{1,3, *}$ \\ ${ }^{1}$ Centre for Ecology and Conservation, University of Exeter, Cornwall Campus, Penryn, TR10 9FE, UK \\ ${ }^{2}$ Department of Genetics, Microbiology and Statistics and IRBio, University of Barcelona, Av. Diagonal 643, 08028 Barcelona, Spain \\ ${ }^{3}$ Environmental and Sustainability Institute, University of Exeter, Cornwall Campus, Penryn, TR10 9FE, UK \\ ${ }^{4}$ Faculty of Veterinary Medicine, Near East University, Nicosia, Mersin 10, N. Cyprus
}

\begin{abstract}
Identifying links between breeding and non-breeding sites in migratory animals is an important step in understanding their ecology. Recognising the relative importance of foraging areas and ascertaining site-specific levels of recruitment can provide fundamental and applied insights. Here, satellite telemetry and the stable isotope ratios $\left(\delta^{13} \mathrm{C}_{1} \delta^{15} \mathrm{~N}\right.$ and $\left.\delta^{34} \mathrm{~S}\right)$ of 230 green turtles Chelonia mydas from a regionally important rookery in northern Cyprus were employed to evaluate the relative importance of 4 foraging areas. A preliminary analysis of stable isotope ratios suggested that a major foraging area had been missed through satellite telemetry as a large proportion of turtles had isotope ratios that did not correspond to sites previously identified. Stable isotope ratios were then employed to select 5 turtles to be fitted with platform terminal transmitters in 2015. All 5 turtles were subsequently tracked to the same location, Lake Bardawil in Egypt. Serially collected tissue samples from 45 females, ranging over 2 to 4 breeding seasons, suggested that foraging site fidelity was very common, with $82 \%$ of females exhibiting extremely high temporal consistency in isotope ratios. Quantifying fidelity allowed an evaluation of foraging areaspecific contributions to each breeding cohort over the past 2 decades and demonstrated that recruitment was unequal among sites, and dynamic over time, with Egypt now currently the major contributor to the nesting aggregation. This work demonstrates the utility of stable isotope analysis to elucidate the spatial ecology of cryptic taxa and illustrates how more robust baselines can be assembled against which to measure the success of future marine conservation initiatives.
\end{abstract}

KEY WORDS: Migration $\cdot$ Foraging $\cdot$ Fidelity $\cdot$ Recruitment $\cdot$ Chelonia mydas $\cdot$ Marine turtles

\section{INTRODUCTION}

Many species undertake migrations, including ontogenetic shifts between successive life-stages (Bolten et al. 1998, Reich et al. 2007) or regular seasonal (Hobson \& Schell 1998) and reproductive migrations (Rubenstein \& Hobson 2004). Philopatric species (animals that return to their natal region to breed) often form genetically distinct populations (Greenwood 1980, Meylan et al. 1990), but not all individuals from the breeding population necessarily migrate to the

${ }^{*}$ Corresponding author: b.j.godley@exeter.ac.uk same non-breeding site (Webster et al. 2002, Bolker et al. 2007). Identifying these links between breeding and non-breeding sites is a priority for species conservation, but tracking migrating animals can be difficult. Large terrestrial species can often be observed or tracked using extrinsic markers (Rubenstein \& Hobson 2004), although this is difficult with smaller, more vagile species because detectability is low. Tracking animals in the marine environment is especially challenging as animals can move across great distances. Satellite telemetry has the ability to provide real-time

(C) The authors 2017. Open Access under Creative Commons by Attribution Licence. Use, distribution and reproduction are unrestricted. Authors and original publication must be credited. 
insight into animal movements, including the large seasonal migrations of marine megavertebrates (Hart \& Hyrenbach 2009, Block et al. 2011, Jeffers \& Godley 2016), identify stock connectivity (Bonfil et al. 2005, Heide-Jørgensen \& Laidre 2006, Zerbini et al. 2006) and guide the implementation of marine protected areas (Scott et al. 2012, Schofield et al. 2013, Revuelta et al. 2015) and time-area closures (Shillinger et al. 2008). Nevertheless, satellite telemetry is expensive and can entail direct costs to the study animals, and therefore, sample size is often limited (Wilson \& McMahon 2006, Godley et al. 2008). However, the satellite data from a few individuals can be scaled-up to infer habitat use at a population level through the use of forensic chemical techniques such as stable isotope analysis (Hobson 2007, Jaeger et al. 2010, Zbinden et al. 2011, Robinson et al. 2016).

Stable isotope analysis (SIA) utilises the stable isotope ratios in the tissue of an animal to evaluate its resource use and migratory origin (Newsome et al. 2007, Hobson et al. 2010). The isotopic composition of a consumer's tissue reflects that of its diet after undergoing a predictable trophic enrichment (Graham et al. 2010), providing a natural intrinsic tag that can link an animal to a location (Hobson 2007). The time period over which the diet is assimilated depends on the tissue-specific turn-over rates, and metabolically active tissues can be selected dependent upon the time frame to be studied (Reich et al. 2008, Hobson et al. 2010). Most studies to date have employed the stable isotope ratios of carbon $\left({ }^{13} \mathrm{C}:{ }^{12} \mathrm{C}\right.$ or $\left.\delta^{13} \mathrm{C}\right)$ and nitrogen $\left({ }^{15} \mathrm{~N}:{ }^{14} \mathrm{~N}\right.$ or $\left.\delta^{15} \mathrm{~N}\right)$ as dietary tracers because these elements are informative about foraging site location and the trophic level of the consumer (Peterson \& Fry 1987, Hobson 1999). Carbon stable isotopes of a consumer reflect those of the primary producer as little fractionation occurs through successive trophic levels $(\sim 1 \%$ ) (DeNiro \& Epstein 1978). More specifically to the marine environment, $\delta^{13} \mathrm{C}$ can exhibit several strong spatial gradients relating to mean temperature and salinity because these factors influence primary production. In general, $\delta^{13} \mathrm{C}$ values increase from higher to lower latitudes, as well as from oceanic to neritic ecosystems, and from pelagic to benthic food sources (Hobson 2007, Koch 2007). The $\delta^{15} \mathrm{~N}$ of a primary producer can be strongly influenced by the mode of nitrogen cycling (Hobson et al. 2010), and substantial trophic discrimination ( 3.4\%) (DeNiro \& Epstein 1981) enables assumptions to be drawn concerning the consumer's trophic level (Hobson \& Welch 1992, Godley et al. 1998). Nitrogen cycling in coastal ecosystems is strongly influenced by anthropogenic inputs of nitro- gen. Sources such as agricultural fertilisers and animal or human waste can elevate nitrate levels, resulting in an increase in $\delta^{15} \mathrm{~N}$ of particulate organic matter that is reflected within the food web (Vander Zanden et al. 2005, Kendall et al. 2007).

Isotopic tracking at finer regional scales can be confounded in situations where there is ambiguity in source isotopic compositions (i.e. multiple geographically distinct areas share a similar isotopic profile), as discrete isotopic differences may not exist (Hobson 2007). In these circumstances, an additional isotope or trace element can be incorporated to supplement the carbon and nitrogen isotopes and possibly establish discrete differences among sites. The stable isotope ratio of sulphur $\left({ }^{34} \mathrm{~S}:{ }^{32} \mathrm{~S}\right.$ or $\left.\delta^{34} \mathrm{~S}\right)$, for example, is particularly useful in differentiating between inshore and offshore feeding populations (Barros et al. 2010) and ontogenetic dietary shifts associated with successional developmental habitats (Cardona et al. 2009). Sulphur isotopes make ideal indicators for identifying the source of primary production as very little trophic discrimination occurs (Koch 2007). Sulphur is considered to truly discriminate between neritic and oceanic ecosystems as phytoplankton and most macroalgae assimilate marine sulphate and are characterised by $\delta^{34} \mathrm{~S}$ values of $\sim 21 \%$ (Cardona et al. 2009). Conversely, benthic primary producers such as seagrasses have a lower and more variable $\delta^{34} \mathrm{~S}$ value because ${ }^{34} \mathrm{~S}$ from sulphide-rich sediments is oxidised back to a sulphate within rhizospheres before being taken up by rooted plants (Fry et al. 1982, Peterson \& Fry 1987, Moncreiff \& Sullivan 2001).

There are some marine isoscapes (spatially explicit predictions for baseline isotope values) available, but these are generally of too coarse a scale to infer the foraging site of a species at a regional level (Hobson et al. 2010, Somes et al. 2010, McMahon et al. 2013). Thus, isotopic approaches to infer foraging area are often validated through the isotopic composition of satellite-tracked individuals (e.g. Jaeger et al. 2010, Zbinden et al. 2011, Seminoff et al. 2012) that can then be used to create species-specific isoscapes, such as those developed for the loggerhead turtle Caretta caretta (Ceriani et al. 2014, Vander Zanden et al. 2015). However, a primary caveat of integrating SIA with satellite telemetry is the effective time lag between these techniques; SIA records the isotopic regime prior to tissue sampling, whilst satellite telemetry tracks the animal after transmitter attachment (Seminoff et al. 2012). Therefore, it is important to assess the foraging site fidelity of the study species before assuming that the isotopic composition of the tracked animal was assimilated at the finally deter- 
mined foraging area (e.g. Vander Zanden et al. 2010, Tucker et al. 2014).

Here, we set out to fully categorise the foraging areas utilised by a green turtle Chelonia mydas population that has been the subject of long-term individual-based research (Stokes et al. 2014). Extensive satellite tracking has identified several key foraging sites for this population (Godley et al. 2002, Stokes et al. 2015), and repeat tracking of a small sample suggested that they exhibit fidelity to these sites (Broderick et al. 2007). We specifically set out to address 4 main research aims: (1) to infer the proportion of the nesting population that forage at each identified site, (2) to quantify foraging site fidelity among adult females, (3) to assess recruitment from each foraging area and (4) to evaluate the effectiveness of stable isotope ratios in monitoring the relative importance of foraging areas over time.

\section{MATERIALS AND METHODS}

\section{Study site}

Alagadi is a double coved beach that stretches along approximately $2 \mathrm{~km}$ of shoreline and is currently the second largest green turtle nesting area in Cyprus, and the fifth most important regionally (Stokes et al. 2015). Long-term monitoring, including saturation tagging and nest protection, was initiated at Alagadi in 1992 with a mean \pm SD of $16 \pm 11.3$ females nesting annually (range $=3-30$, from 1993 to 2000). Since 2008, the number of females nesting each year has increased rapidly to $46.5 \pm 2.4$ (range $=$ 23-86, 2008 to 2015).

\section{Satellite telemetry}

Between 1998 and 2011, 23 Platform Terminal Transmitters (PTTs; see Supplement 1 at www.intres.com/articles/suppl/m582p201_supp.pdf) were attached to 21 female green turtles (Godley et al. 2002, Broderick et al. 2007, Stokes et al. 2015) and 2 males (Fig. 1; Wright et al. 2012). All PTTs were attached on nesting beaches in northern Cyprus using standard protocols set out in Godley et al. (2002), with satellite data processing and conclusive endpoint destinations as determined by Stokes et al. (2015). Satellite tracking identified 4 distinct regions as important foraging areas for Mediterranean green turtles: (1) several sites around Turkey and Cyprus (hereafter Turkey-Cyprus); (2) the Gulf of Sirte and the LibyaTunisia border (hereafter West Libya); (3) the Gulf of Bomba (in eastern Libya); and (4) Egypt (Fig. 1, Stokes et al. (2015)). Subsequent to a preliminary analysis of the stable isotope ratios, we targeted 5 specific females during the 2015 breeding season for the attachment of Wildlife Computer SPOT-293A tags (see Supplement 1).

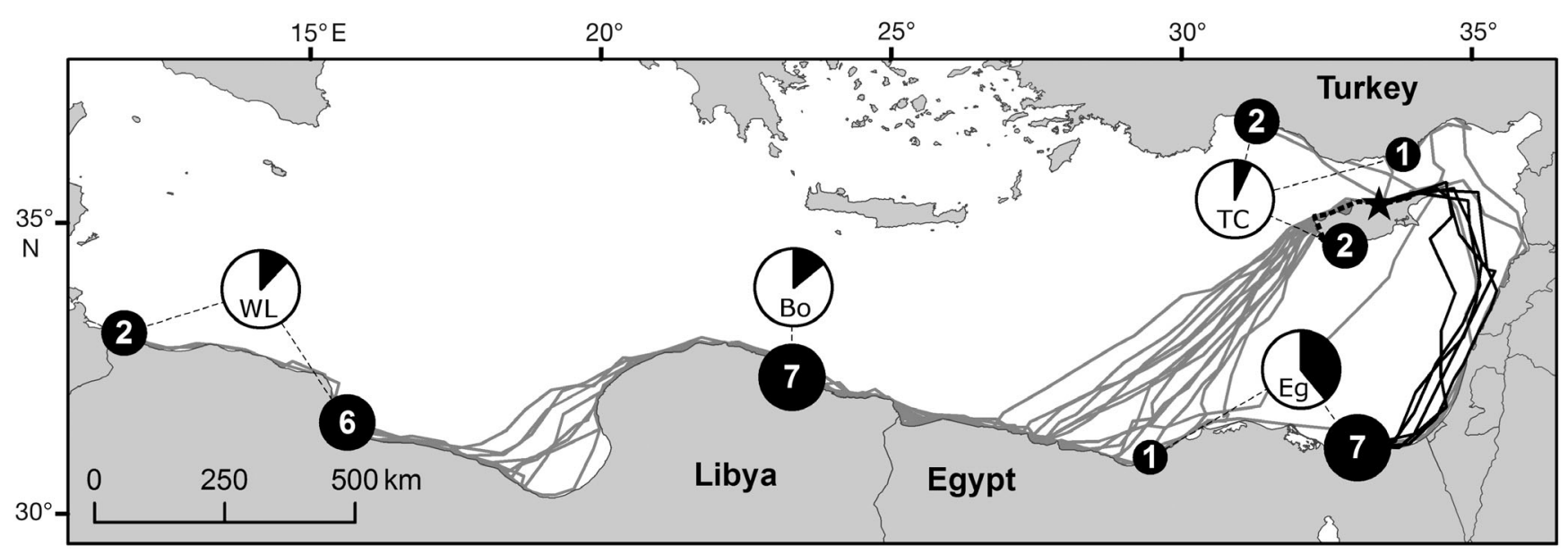

Fig. 1. Post-nesting green turtle satellite tracks from Cyprus to 4 broad-scale foraging areas: Turkey-Cyprus (TC), which combines several foraging sites clustered around Turkey and Cyprus; West Libya (WL), which combines 2 sites (the Gulf of Sirte and a site on the Libyan-Tunisian border); the Gulf of Bomba (Bo) in east Libya; and Egypt (Eg), which combines 2 sites (Gulf of Arab and Lake Bardawil). Light grey tracks: individuals satellite tracked between 1998 and 2011 from Stokes et al. (2015) and Wright et al. (2012); thick black dashed track: previously unpublished male tracked to southern Cyprus (PTT = 52818); black tracks: individuals satellite tracked in 2015 to Lake Bardawil, Egypt. Numbers indicate how many individuals were satellite tracked to each foraging area. Pie charts segmented to represent the proportion of individuals assigned to each foraging area based on their stable isotope composition from the 2015 analysis. The black section of each pie is equal to the proportion of the 165 turtles assigned to that specific foraging area 


\section{Tissue sample collection}

A total of 323 tissue samples were collected from 230 green turtles on Alagadi beach in northern

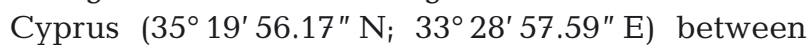
2006 and 2015. Tissue samples were collected from post-nesting females during the breeding season (mid-May until end of July), with the exception of 1 male encountered at Alagadi beach still coupled to the emergent female (the other satellite-tracked male was not tissue sampled; see Supplement 1). Tissue samples comprising of a small epidermal biopsy $\left(<0.5 \mathrm{~cm}^{2}\right)$ were taken from the trailing edge of the fore flipper and stored in $96 \%$ ethanol until sample preparation. All turtles were individually marked using both external flipper tags and Passive Integrated Transponder (PIT) tags (Stokes et al. 2014).

\section{Stable isotope analysis}

We analysed the stable isotopes of carbon, nitrogen and sulphur from green turtle epidermal tissue samples (Seminoff et al. 2006, Reich et al. 2008) following a standard protocol (Ceriani et al. 2014), with the exception that samples were dried at $60^{\circ} \mathrm{C}$ for 48 to $72 \mathrm{~h}$. Approximately $0.7 \pm 0.1 \mathrm{mg}$ of each sample was weighed into a tin capsule, sealed and analysed for carbon and nitrogen. Isotope analysis was performed at the Stable Isotope Facility of the Environment and Sustainability Institute (ESI; University of Exeter, Penryn Campus) via a continuous flow isotope ratio mass spectrometer (CF-IRMS) using a Sercon Integra2 stable isotope analyser. A greater sample mass was required for sulphur isotope analysis, with approximately $5 \pm 0.5 \mathrm{mg}$ of sample sealed into a tin capsule together with a small amount $(<1 \mathrm{mg})$ of vanadium pentoxide to aid combustion of the larger sample quantity. The analysis of sulphur isotopes was conducted at Elemtex in Launceston, UK using an ANCA SL attached to a Sercon 2020 CF-IRMS.

Stable isotope ratios are expressed using a conventional notation as $\delta$ values defined as parts per thousand or per mil (\%) according to the following equation as per Bond \& Hobson (2012):

$$
\delta X=\left[\left(R_{\text {sample }} / R_{\text {standard }}\right)-1\right]
$$

where $X$ is ${ }^{15} \mathrm{~N},{ }^{13} \mathrm{C}$ or ${ }^{34} \mathrm{~S} ; R_{\text {sample }}$ is the corresponding ratio of the heavier to lighter isotopes $\left({ }^{15} \mathrm{~N}:{ }^{14} \mathrm{~N}_{i}{ }^{13} \mathrm{C}:{ }^{12} \mathrm{C}\right.$ or ${ }^{34} \mathrm{~S}:{ }^{32} \mathrm{~S}$ ); and $R_{\text {standard }}$ is relative to the international standards of atmospheric nitrogen, Pee Dee Belemnite and Vienna Cañon Diablo Trolite, respectively. The standard deviations of the laboratory reference materi- als among runs for $\delta^{15} \mathrm{~N}$ were $0.18 \%$ for IAEA N1 $\left(\delta^{15} \mathrm{~N}\right.$ $=+0.4 \%$ ) and $0.25 \%$ for IAEA N2 $\left(\delta^{15} \mathrm{~N}=+0.25 \%\right)$; for $\delta^{13} \mathrm{C}$ they were $0.10 \%$ for IAEA CH6 $\left(\delta^{13} \mathrm{C}=-10.45 \%\right)$, $0.16 \%$ for IAEA Isvec $\left(\delta^{13} \mathrm{C}=-46.6 \%\right.$ ) and $0.19 \%$ for IAEA nbs-18 $\left(\delta^{13} \mathrm{C}=-5.01 \%\right)$; and for $\delta^{34} \mathrm{~S}$ they were $0.32 \%$ for IAEA S1 $\left(\delta^{34} \mathrm{~S}=-0.3 \%\right), 0.29 \%$ for IAEA S2 $\left(\delta^{34} \mathrm{~S}=+22.7 \%\right.$ o $), 0.42 \%$ for USGS $42\left(\delta^{34} \mathrm{~S}=+7.8 \%\right.$ o) and $0.26 \%$ for USGS $43\left(\delta^{34} \mathrm{~S}=+10.21 \%\right.$ ).

\section{Selecting samples}

Tissue samples were available for some females over multiple breeding seasons, and these were employed to quantify foraging site fidelity. However, to avoid pseudoreplication when inferring foraging area use at a population scale, we selected a single epidermal tissue sample for each turtle. A more defined criteria was employed for selecting tissue samples for satellite-tracked turtles to ameliorate the time lag between satellite telemetry and SIA. For satellite-tracked turtles, we selected tissue samples using the following criteria in order of preference: (1) sample mass available to analyse all 3 isotopes; (2) sample collected during the breeding season subsequent to satellite tracking, (3) sample collected during the PTT deployment or (4) sample collected temporally closest to when the turtle was satellite tracked (see Supplement 1). No tissue samples were available for 4 satellite-tracked turtles, and so these were omitted from this study (see Supplement 1). When multiple tissue samples were available for turtles that were not satellite tracked, we selected the most recent sample available to minimise any temporal variation in baseline isotopic values that might occur over long time frames.

\section{Control of possible methodological biases}

To evaluate additional sources of variation, we analysed 20 paired samples to determine if lipid extraction was necessary (Post et al. 2007). Paired $t$-tests were conducted on lipid extracted and non-lipid extracted samples (see Supplement 2) with no significant differences found for $\delta^{15} \mathrm{~N}$ values (paired $t$-test, $t_{19}=$ $1.70, p=0.11$; Fig. S2a). Statistically significant differences were detected between paired samples for $\delta^{13} \mathrm{C}$ (paired $t$-test, $t_{19}=-4.0, \mathrm{p}<0.001$; Fig. S2b), but the mean difference in $\delta^{13} \mathrm{C}$ due to lipid extraction $($ mean $=-0.2 \%$, range $=-0.3$ to $0.1 \%$ ) was judged biologically irrelevant considering the mean difference in $\delta^{13} \mathrm{C}$ among sites $(1.7 \%)$. Thus, lipid extraction was deemed unnecessary. 
Some disparity exists within the literature concerning the effect that a $>70 \%$ ethanol concentration can have on the isotopic values of stored tissue samples (Hobson et al. 1997, Tillberg et al. 2006, Barrow et al. 2008, Kaufman et al. 2014). Therefore, as tissue samples for this study were stored in a $96 \%$ ethanol concentration, we conducted paired $t$-tests on tissue samples collected simultaneously from 33 individuals and stored in $96 \%$ and $70 \%$ ethanol concentration for up to 5 mo (see Supplement 3). We found no significant differences between samples $\left(\delta^{15} \mathrm{~N}\right.$, paired $t$-test, $t_{32}=$ $0.67, \mathrm{p}=0.51$, Fig. S3a; $\delta^{13} \mathrm{C}$ values, paired $t$-test, $t_{32}=$ $-0.13, p=0.90$, Fig. S3b), meaning that no consistent enrichment or depletion was observed. Possible sources of variation in $\delta^{34} \mathrm{~S}$ values were not investigated due to limitations in tissue sample availability.

\section{Assigning turtles to the foraging areas}

Nominal assignment approaches are commonly used to predict the foraging locations of a population using stable isotope signatures calibrated from the satellite telemetry of a subset of individuals (Wunder 2012). We broadly followed previously described methods (Ceriani et al. 2012, Pajuelo et al. 2012, Vander Zanden et al. 2015) to predict foraging area using a discriminant function analysis (see Supplement 4), with a secondary classification method as per Zbinden et al. (2011) to distinguish between 2 sites that were isotopically similar.

\section{Investigating foraging site fidelity}

Evidence for foraging site fidelity has already been demonstrated for this population of green turtles through the repeat satellite tracking of 3 individuals (Broderick et al. 2007). To further investigate foraging site fidelity among a broader sample, we used serially collected samples from 45 females, with 33 sampled over 2 seasons, 9 sampled over 3 seasons and 3 sampled over 4 seasons. Samples for 42 of the females were collected from consecutive breeding seasons including all females sampled for $>2$ seasons. The other 3 females were sampled for 2 breeding seasons, but these were not consecutive as they were not sampled for a single intermediate breeding season. To investigate fidelity, we used a repeatability analysis to test the temporal consistency in isotope ratios with the identity of the turtle as the grouping factor and the predicted foraging area as a covariate (see Supplement 5).

\section{Evaluating foraging area-specific annual contributions to the breeding cohort}

If foraging site fidelity is typical within the Alagadi population, then the individually based nesting data collected at Alagadi since 1992 (Stokes et al. 2014) can be used to retrospectively evaluate the foraging area-specific contributions to each breeding cohort based on the turtle's unique identification. Although the analysis is limited to nesting females that were satellite tracked, or had their foraging area inferred through SIA, some of these females have nested consistently since 1992, and their unique identity can therefore be used to gain an insight into foraging area dynamics prior to the initiation of the tissue sampling regime. For each year that a turtle nested, it was included as a contributor from its respective foraging area, and therefore, some females are represented in multiple seasons.

\section{RESULTS}

A broad range in stable isotope values were found $\left(\delta^{15} \mathrm{~N}=+2.0 \%\right.$ o to $+13.0 \%$, $\delta^{13} \mathrm{C}=-16.3 \%$ o to $-4.9 \%$ o and $\delta^{34} \mathrm{~S}=+0.2 \%$ to $+20.2 \%$; Fig. 2), and pairwise comparisons showed all pairs of isotopes to be significantly correlated (Pearson's product-moment correlation coefficient, $\mathrm{p}<0.001$ in all cases, $\delta^{13} \mathrm{C}$ and $\delta^{15} \mathrm{~N}, \mathrm{r}=-0.26 ; \delta^{15} \mathrm{~N}$ and $\delta^{34} \mathrm{~S}, \mathrm{r}=0.23 ; \delta^{13} \mathrm{C}$ and $\delta^{34} \mathrm{~S}$, $r=-0.75$, see Supplement 6). Turtles tracked to Bomba exhibited high $\delta^{13} \mathrm{C}$ values and low $\delta^{34} \mathrm{~S}$ values, whereas the turtles tracked to Egypt had high $\delta^{15} \mathrm{~N}$ values compared to the other foraging areas. Turtles tracked to Turkey-Cyprus and West Libya were nearly isotopically indistinguishable in terms of $\delta^{13} \mathrm{C}$ and $\delta^{15} \mathrm{~N}$, but individuals from Turkey-Cyprus exhibited higher $\delta^{34} \mathrm{~S}$ values compared to those from West Libya, providing isotopic differentiation between these sites (Figs. $3 \& 4$ ).

\section{Inferring foraging area use}

The initial composition of the data, validated by the 19 turtles satellite tracked before 2015, strongly suggested that the pre-defined foraging areas did not fully characterise the isotope ratios of the turtle population (Fig. 2). Thus, we hypothesised that a foraging area had been missed, or under-represented, through previous satellite tracking effort.

To substantiate this hypothesis, we conducted a preliminary discriminant analysis using $\delta^{13} \mathrm{C}$ and $\delta^{15} \mathrm{~N}$ 


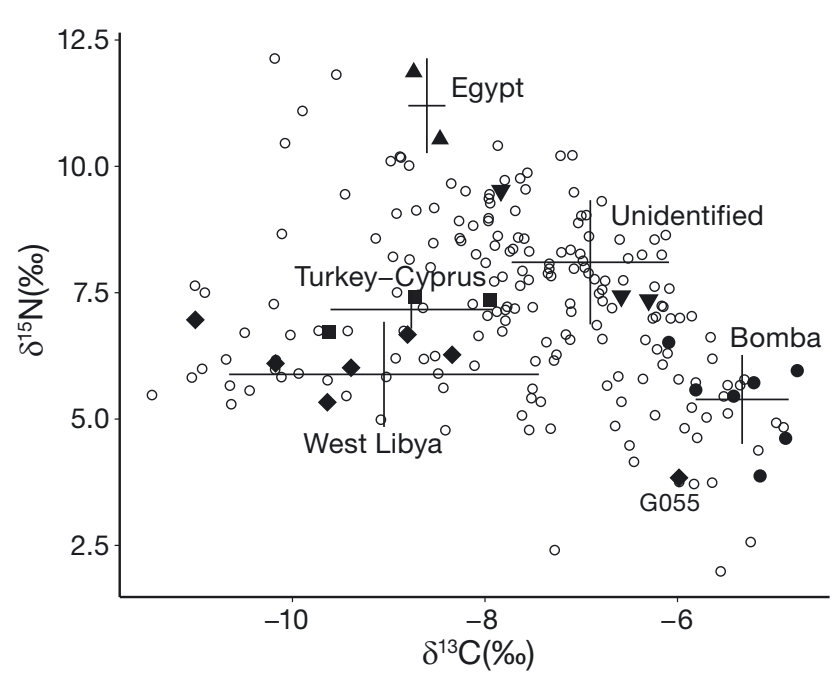

Fig. 2. Bivariate plot of $\delta^{13} \mathrm{C}$ and $\delta^{15} \mathrm{~N}$ values for green turtles included in the preliminary discriminant analysis. Crosses represent the mean $\pm \mathrm{SD}$ of isotopic values for satellitetracked turtles used to calibrate each foraging area. Filled shapes represent turtles satellite tracked to Bomba $(n=7$; circles), Egypt ( $\mathrm{n}=2$; triangles), Turkey-Cyprus ( $\mathrm{n}=3$; squares) and West Libya ( $\mathrm{n}=7$; diamonds) along with individuals selected to characterise the unidentified foraging area $(n=3$; inverted triangles). Open circles: individuals of unknown foraging area $(n=183)$. Note: One data point removed for greater graph clarity $\left(\delta^{13} \mathrm{C}<-14 \%\right)$. G055 highlighted as an isotopic mismatch; satellite-tracked to West Libya but exhibited an isotopic signature corresponding to Bomba

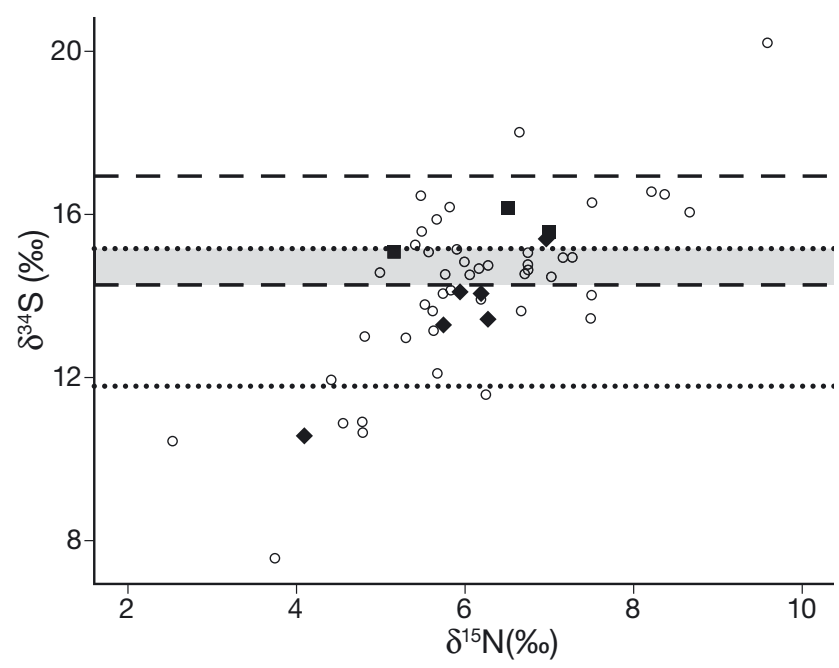

Fig. 3. Classification of individuals to Turkey-Cyprus or West Libya from the combined foraging area TCWL based on the $95 \%$ CI of $\delta^{34} \mathrm{~S}$ values of satellite-tracked turtles used to calibrate Turkey-Cyprus ( $\mathrm{n}=3$; squares) and West Libya ( $\mathrm{n}=6$; diamonds); dashed lines: upper and lower CI for Turkey-Cyprus; dotted lines: upper and lower CI for West Libya; open circles: turtles to be assigned. Individuals within the grey overlapping region were unassigned $(n=15)$; individuals above the grey region were assigned to TurkeyCyprus $(n=11)$, and those below were assigned to West Libya $(\mathrm{n}=19)$

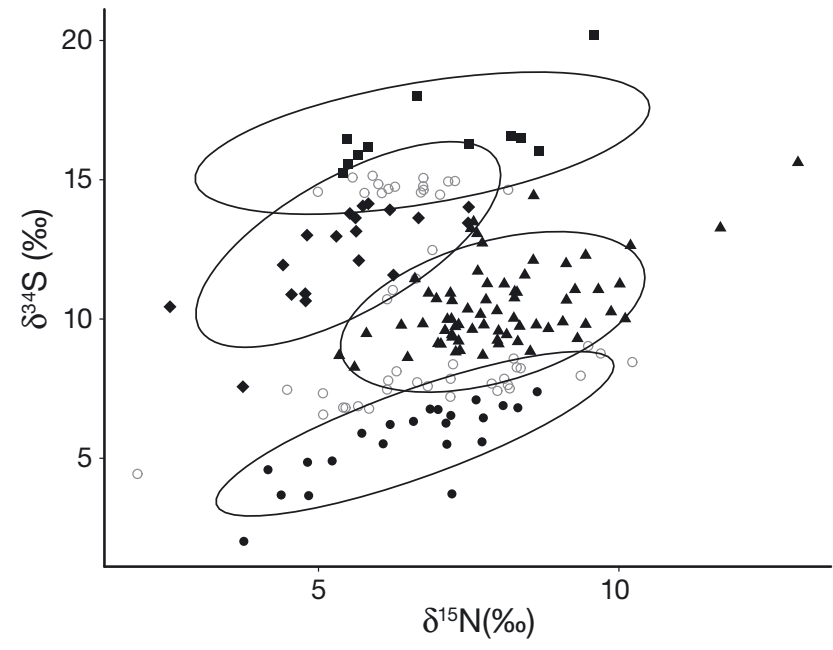

Fig. 4. $\delta^{15} \mathrm{~N}$ and $\delta^{34} \mathrm{~S}$ values for green turtles predicted to forage in Bomba ( $n=22$; filled circles), Egypt ( $n=65$; triangles), Turkey-Cyprus ( $\mathrm{n}=11$; squares), West Libya $(\mathrm{n}=19$; diamonds), or an unassigned location ( $\mathrm{n}=48$; open circles). Ellipses set at $95 \%$ CI (total $n=165)$

values to obtain prediction probabilities for turtles that might forage in the area not previously characterised. We selected 3 turtles with isotope ratios corresponding to this uncalibrated isospace, in addition to the 19 satellite-tracked turtles, to calibrate a discriminant analysis and predict the putative foraging area for 181 turtles (see Table S2 in Supplement 4 \& Supplement 7). We then produced a list of 48 turtles that were likely (at $>80 \%$ probability) to forage in the isotopically uncharacterised foraging area (Fig. 2).

This list of 48 turtles was subsequently used during the 2015 breeding season to select 5 females for PTT deployment based on their prediction probabilities. Eight of those 48 turtles nested at Alagadi that season, of which 6 had a $>90 \%$ probability of foraging in the uncharacterised area and were specifically targeted for PTT deployment. On their next successful nesting attempt, 5 of these 6 turtles were fitted with PTTs and tracked for 58 to $146 \mathrm{~d}$ (mean $\pm \mathrm{SD}=80.6 \pm$ 37.13; Fig. S1). All 5 turtles were tracked to the same foraging area, Lake Bardawil in Egypt (Fig. 1; Supplement 1, Fig. S1) where the PTTs then failed, most likely due to the hypersaline conditions within the lake as this is a common occurrence among all turtles tracked to this location (Nada et al. 2013, Kevin Ng pers. comm.).

Subsequent to the 2015 breeding season, and with the full isotopic composition of the turtle population now validated through the satellite telemetry of 23 turtles, we conducted a second discriminant analysis with the addition of a third stable isotope $\left(\delta^{13} \mathrm{C}, \delta^{15} \mathrm{~N}\right.$ and $\delta^{34} \mathrm{~S}$ ). Tissue samples collected in 2015 from not 
previously sampled females $(\mathrm{n}=27)$ and some alternate tissue samples sourced for some females from other years $(n=21)$ were incorporated within this analysis, whilst some females $(n=42)$ from the preliminary analysis were excluded, as the initial sample mass was not always adequate to analyse the greater quantity necessary for sulphur; this simultaneously excluded 1 turtle (G044) satellite tracked to West Libya (see Table S2 in Supplement 4). Discrete differences were found in the combined isotopic values (MANOVA, Pillai's trace test, $F_{3,19}=6.54, \mathrm{p}<0.001$ ), yet multiple pairwise comparisons conducted with Tukey's honestly significant difference (HSD) still failed to identify discrete differences among all foraging areas (Table 1). For this reason, we combined the 2 foraging areas that were not discretely differentiated (Turkey-Cyprus and West Libya; TCWL) to establish discrete isotopic differences among 3 groups (Bomba, Egypt and TCWL; Table 1). With normal distributions found for the 3 isotopes, and the variance among foraging areas homogenous, we employed a linear discriminant function analysis. We used nonuniform priors using the number of turtles tracked to each site from the satellite telemetry (Royle \& Rubenstein 2004, Vander Zanden et al. 2015) and a posterior probability of assignment set at $80 \%$. The discriminant analysis was evaluated using the leave-one-out cross validation method with $95.7 \%$ of turtles from the training data correctly reclassified. The putative foraging area was predicted for 132 of 165 turtles (80\%), with $45(27 \%)$ assigned to the combined foraging area of TCWL.

The 45 turtles assigned to TCWL were then subjected to a secondary classification method based on their $\delta^{34} \mathrm{~S}$ values because this discriminating criterion

Table 1. Tukey HSD results comparing stable isotope values in green turtles among (a) the 4 foraging areas and (b) 3 foraging areas. TCWL: Turkey-Cyprus and West Libya combined. Significant $p$-values $(p<0.05)$ adjusted for multiple tests in bold

\begin{tabular}{|lccc|}
\hline Foraging areas & Nitrogen & Carbon & Sulphur \\
\hline (a) & & & \\
Bomba; Egypt & $<\mathbf{0 . 0 0 1}$ & $\mathbf{0 . 0 1}$ & $<\mathbf{0 . 0 0 1}$ \\
Bomba; Turkey-Cyprus & 0.56 & $\mathbf{< . 0 0 1}$ & $\mathbf{< 0 . 0 0 1}$ \\
Bomba; West Libya & 0.66 & $\mathbf{< . 0 0 1}$ & $<\mathbf{0 . 0 0 1}$ \\
Egypt; Turkey-Cyprus & 0.1 & 0.32 & $\mathbf{0 . 0 4}$ \\
Egypt; West Libya & $\mathbf{0 . 0 1 1}$ & 0.36 & 0.31 \\
Turkey-Cyprus; West Libya & 0.98 & 0.98 & 0.5 \\
(b) & & & \\
Bomba; Egypt & $<\mathbf{0 . 0 0 1}$ & $<\mathbf{0 . 0 0 1}$ & $<\mathbf{0 . 0 0 1}$ \\
Bomba; TCWL & 0.32 & $<\mathbf{0 . 0 0 1}$ & $<\mathbf{0 . 0 0 1}$ \\
Egypt; TCWL & $<\mathbf{0 . 0 0 1}$ & 0.12 & $\mathbf{0 . 0 4 5}$ \\
\hline
\end{tabular}

showed the greatest statistical differences among sites (Table 1). The pooled means and 95\% confidence intervals (CI) for the turtles satellite tracked to each foraging area were used to create an overlap in which turtles could not be reliably assigned to either foraging area; these were then included with the turtles unassigned from the discriminant analysis. Those turtles with a $\delta^{34} \mathrm{~S}$ value greater or lower than the overlap created by the CI were assigned to TurkeyCyprus or West Libya, respectively (Fig. 3). The combination of the 2 nominal assignment approaches resulted in 11 turtles $(7 \%, \mathrm{n}=165)$ predicted to forage in Turkey-Cyprus, 19 (12\%) in West Libya, 65 $(39 \%)$ in Egypt, $22(13 \%)$ in Bomba and a total of 48 remaining unassigned $(29 \%, 33$ from the discriminant function analysis and 15 from the classification method) (Figs. 1 \& 4, Supplement 8).

\section{Foraging site fidelity}

The $\delta^{13} \mathrm{C}$ and $\delta^{15} \mathrm{~N}$ values were remarkably consistent over multiple seasons with highly significant repeatability estimates $\left(\delta^{15} \mathrm{~N}: \mathrm{R} \pm \mathrm{SE}=0.65 \pm 0.09\right.$, $95 \% \mathrm{CI}=0.46-0.79, \mathrm{p}=0.001$, Fig. $5 \mathrm{a} ; \delta^{13} \mathrm{C}: \mathrm{R}=$ $0.74 \pm 0.07,95 \% \mathrm{CI}=0.58-0.84, \mathrm{p}=0.001$, Fig. $5 b)$. The $\delta^{15} \mathrm{~N}$ values were more variable than $\delta^{13} \mathrm{C}$ values, with $65 \%$ of samples differing by $<1 \%$ and $76.7 \%$ by $<1.5 \%$ in subsequent sampling, (always $\geq 2$ yr apart) within an overall range in $\delta^{15} \mathrm{~N}$ among these females of $8.8 \%$. In contrast, $91.7 \%$ of the $\delta^{13} \mathrm{C}$ values differed by $<1 \%$ and $96.7 \%$ by $<1.5 \%$ within an overall range of $6.1 \%$. As carbon isotopes are a more accurate predictor for the source of primary production (Michener \& Kaufman 2007), we contrasted the difference in $\delta^{13} \mathrm{C}$ among serially collected samples to the mean difference in $\delta^{13} \mathrm{C}$ among sites $(1.7 \%)$. This gave us a conservative estimate of $82 \%$ of females (37 of the 45 females) remaining site-faithful as these individuals did not exhibit a difference $>1 \%$ in $\delta^{13} \mathrm{C}$ among seasons. Thus, we assumed that foraging site fidelity is extremely common within this population. Only 2 females exhibited differences $>1.5 \%$ in $\delta^{13} \mathrm{C}$ among seasons $(4.5 \%)$, suggesting that plasticity in foraging site fidelity does exist, although it is relatively rare (Fig. 5). An isotopic mismatch was also noted for 1 turtle satellite tracked to West Libya in 2003 because it had isotopic values more suggestive of the Gulf of Bomba when tissue was sampled during the subsequent breeding season (Fig. 2; turtle G055). However, this turtle appeared to remain faithful to Bomba for the subsequent 2 interbreeding intervals. 

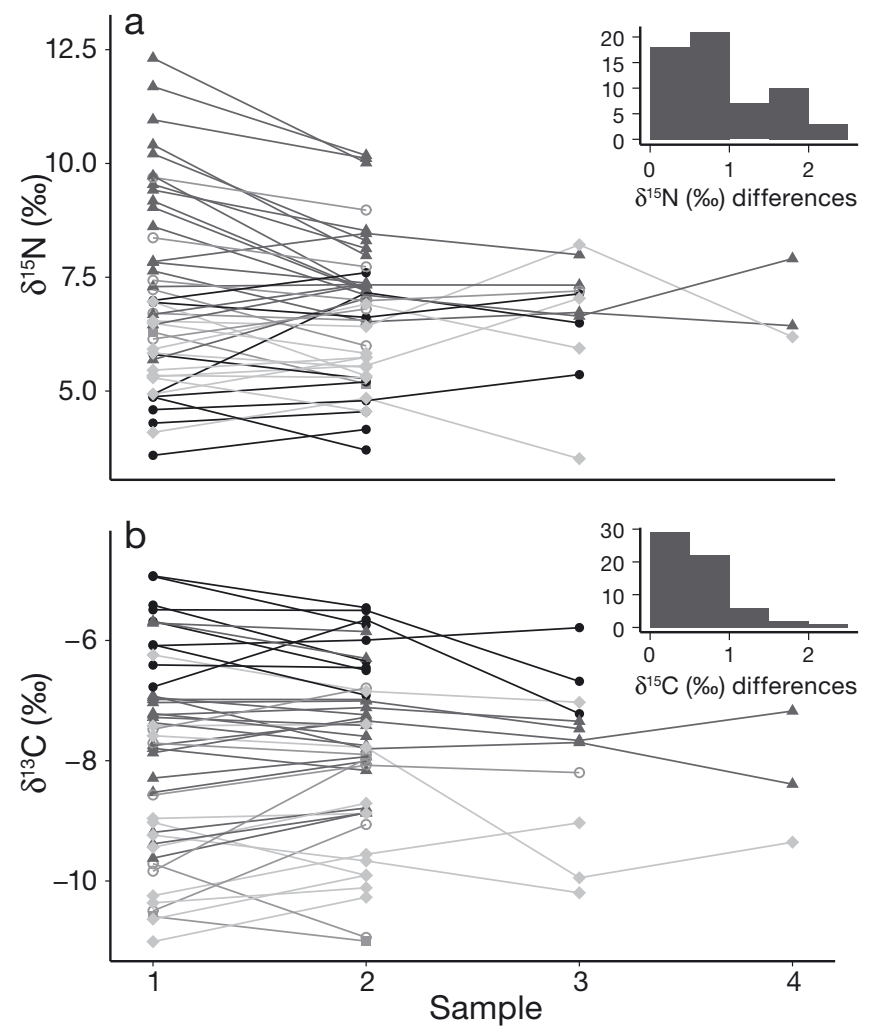

Fig. 5. Temporal consistency of isotopic values for serially collected tissue samples of green turtles over successive breeding seasons $(\mathrm{n}=45)$ for (a) $\delta^{15} \mathrm{~N}$ and (b) $\delta^{13} \mathrm{C}$ values. Subplots represent within individual absolute differences among serially collected samples using the first sample as a reference. Filled circles: Bomba; triangles: Egypt; squares: Turkey-

Cyprus; diamonds: West Libya; open circles: unassigned

\section{Evaluating foraging area-specific annual contributions to the breeding cohort}

Foraging site fidelity being typical within this population, we were able to utilise the individuallybased nesting data collected at the breeding study site since 1992 (Stokes et al. 2014) retrospectively to evaluate foraging area specific contributions to each breeding cohort. We found that the contributions to the annual breeding cohort from each foraging area were unequal among years (generalised linear model, GLM, $\left.F_{3,84}=8.91, \mathrm{p}<0.001\right)$ with a general biannual variation characteristic among foraging areas (Fig. 6, Supplement 9). The trends identified for each foraging area suggest that Bomba was historically the major contributor to the breeding population, but recent trends suggest that there has not been any substantial increase in the number of females from this site (Fig. 6a). Egypt, and in particular Lake Bardawil, may have only contributed a few

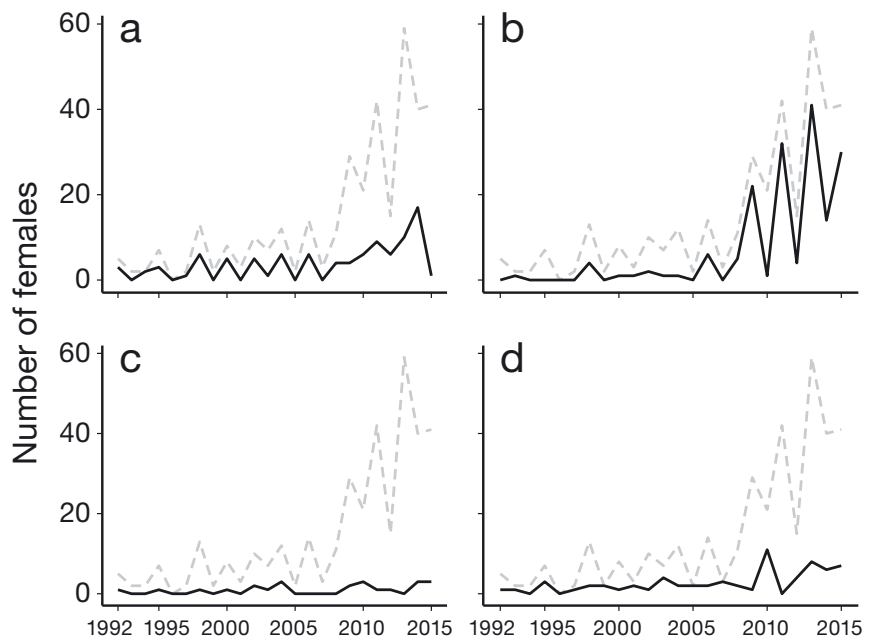

Fig. 6. Total number of females nesting at Alagadi (19922015) (grey broken line) with the solid black line showing foraging area-specific contributions to the breeding cohort from (a) Bomba, (b) Egypt, (c) Turkey-Cyprus and (d) West Libya

individuals to each breeding cohort until 2010, but then the number of females significantly increased from this site, with the result that Egypt is presently the single most important foraging area for the Alagadi rookery (Fig. 6b). The trends for Turkey-Cyprus and West Libya (Fig. 6c \& d, respectively) suggest that these foraging areas only contribute a few individuals to each breeding cohort, which is in stark contrast to the inferred importance of these sites from the satellite telemetry (Fig. 1).

\section{DISCUSSION}

The stable isotope ratios of the study population have significantly altered our perception of the relative importance of the 4 foraging areas identified through satellite telemetry and allowed us to quantify foraging site fidelity and investigate foraging area dynamics. Based on our experience here, we advocate the use of SIA prior to, and during, satellite tracking campaigns and discuss in turn the major insights that we have gained from the present study.

\section{Selecting the elements for stable isotope analysis}

Stable isotopes are now commonly used to track animal migration across broad spatial scales for both terrestrial and marine species (Rubenstein \& Hobson 2004, Michener \& Kaufman 2007). However, this study and others (e.g. Tucker et al. 2014) did 
not find discrete isotopic differences among all nonbreeding sites at a regional level given that the 2 most geographically separated foraging areas (Turkey-Cyprus and West Libya) were the most similar for $\delta^{13} \mathrm{C}$ and $\delta^{15} \mathrm{~N}$. The predictable increase of $\delta^{13} \mathrm{C}$ towards the lower latitudes (Hobson 2007, Koch 2007) was confounded as our foraging areas were located on the north and south continental faces. Without the addition of the sulphur isotope ratios, we could not have reliably predicted the foraging area for a large proportion of turtles within this population.

The strong negative correlation found between $\delta^{13} \mathrm{C}$ and $\delta^{34} \mathrm{~S}$ was previously undescribed among seagrass habitats and resulted in sulphur being the more informative for this study population. Sulphur was specifically selected for this study because green turtles are thought to feed predominantly on seagrasses within the Mediterranean (Cardona et al. 2010) that derive their nutrients from the marine sediments as opposed to the open ocean environment. Benthic macroalgae and seagrasses therefore can vary considerably among sites because the marine sedimentary cycle (reviewed by Thode 1991) produces a wide range in $\delta^{34} \mathrm{~S}$ values as the reduction of seawater sulphate to $\mathrm{H}_{2} \mathrm{~S}$ in shallow sediments is influenced by rock type and accretion rates. Thus, we considered that these factors should produce variable $\delta^{34} \mathrm{~S}$ values at a local level despite the similarity in habitat type. However, strong intrasite differences have been found in the $\delta^{34} \mathrm{~S}$ values of seagrasses attributed to the interaction of particulate organic matter and oxygen levels exuded by seagrass roots (Oakes \& Connolly 2004). Seagrass samples taken only hundreds of metres apart can have as great a difference in $\delta^{34} \mathrm{~S}$ as samples taken thousands of kilometres apart (Connolly et al. 2004). Nevertheless, such variation over small geographic scales is incorporated within large megavertebrates, such as green turtles, that forage over tens of square kilometres (Broderick et al. 2007, Christiansen et al. 2017), and the diet assimilated provided distinct differences among distant foraging areas. In a similar study, Tucker et al. (2014) did not find $\delta^{34} \mathrm{~S}$ in loggerhead turtles Caretta caretta to be informative because the intra-foraging site variation in $\delta^{34} \mathrm{~S}$ values encompassed a much greater range (11 to $15 \%$ at several sites), effectively masking among-site differences. However, loggerhead turtles consume a broader diet over a greater range of depths than green turtles, and, importantly, they do not necessarily forage in food webs based on benthic primary production.

\section{Using stable isotope analysis to target satellite tracking}

The application of SIA validated by satellite telemetry is almost routine now when evaluating foraging areas (Rubenstein \& Hobson 2004, Hobson et al. 2010), but the SIA is commonly conducted subsequent to the satellite telemetry. The present study has effectively demonstrated that SIA conducted prior to, or during, satellite telemetry campaigns can greatly augment the study by providing scientific guidance to identify specific groups of individuals for PTT attachment and infer the most likely number of transmitters necessary to identify isotopically discrete foraging sites.

\section{Assigning turtles to their foraging area}

The combined results of the nominal assignment approaches predicted the foraging areas for $71 \%$ of the turtles sampled. This provided a sample size of 117 turtles, from the 165 analysed, to assess the relative importance of the foraging areas using SIA, and this yielded substantially different results from those inferred from satellite telemetry (Fig. 1). The satellite telemetry conducted before 2015 inferred that $65 \%$ of green turtles from northern Cyprus were foraging in Libya (35\% in West Libya and 30\% in the Gulf of Bomba), $22 \%$ in Turkey-Cyprus and 13\% in Egypt (Wright et al. 2012, Stokes et al. 2015, authors' unpubl. data). In contrast, SIA suggested that $25 \%$ foraged in Libya (12\% in West Libya and $13 \%$ in the Gulf of Bomba), $7 \%$ in Turkey-Cyprus and 39\% in Egypt but with $29 \%$ undetermined. The difference between these 2 techniques arises from several factors, including the limited sample size associated with satellite tracking relative to SIA sampling, interannual variations in the relative contributions from each foraging area and, most importantly in this case, the recent demographic shift causing an increase in turtles recruiting from Lake Bardawil. The observed differences in results from these techniques underline the need to conduct SIA, in addition to satellite tracking, over sufficient time frames to prevent erroneous conclusions because both the relative contributions from foraging areas and baseline isotopic values are dynamic. These techniques should complement each other, as SIA will never be as accurate as satellite telemetry but satellite telemetry will rarely incorporate such robust sample sizes. Thus, a sustained tissue sampling protocol should be supported by satellite telemetry as resources permit. 


\section{Ascertaining foraging site fidelity}

This study builds upon a growing body of evidence that green turtles (Broderick et al. 2007, Vander Zanden et al. 2013, Shimada et al. 2014, 2016) and other marine turtle species (Schofield et al. 2010, Thomson et al. 2012, Tucker et al. 2014, Pajuelo et al. 2016) show high levels of fidelity to non-breeding sites. The ability to isotopically track some individuals for up to 4 breeding seasons, with a temporal frame of approximately 2 to $8 \mathrm{yr}$, presented clear evidence for a high degree of fidelity to the pre-defined foraging areas. We consider our estimate of $82 \%$ of females exhibiting fidelity to be conservative as only 2 females $(4.5 \%)$ exhibited substantial differences in $\delta^{13} \mathrm{C}(>1.5 \%)$, which would be more indicative of a move over a broad spatial scale, considering the mean difference in $\delta^{13} \mathrm{C}$ among our sites. However, plasticity does exist, and Stokes et al. (2015) also noted evidence from satellite telemetry of secondary movements after turtles had taken up residency, but these were also relative exceptions (4 individuals out of a total of 29 tracked conclusively to foraging grounds). These movements were generally between neighbouring foraging sites, and in some cases only temporary, but this suggests that foraging site fidelity is not hard-wired and is most likely subject to external variables such as resource availability.

\section{Monitoring foraging site contribution over time}

Significant temporal change in the number of individuals originating from foraging areas can be informative of foraging area dynamics without the need to conduct site-based surveys. In this case, the foraging area-specific trends in the annual contribution to each nesting cohort clearly demonstrate that the increase in the number of females nesting at Alagadi is primarily being driven by the recruitment of turtles that forage in Egypt (Lake Bardawil). Several alternative and not mutually exclusive drivers could result in such a foraging area-specific increase in recruitment. These include (1) an increase in the survival probabilities of juveniles and sub-adults as industrial fisheries are excluded (Casale 2011, Casale \& Heppell 2016), (2) greater foraging resources reducing the age to sexual maturity (Bjorndal et al. 2013), (3) temporal oscillations in sea surface currents, such as those dictated by the Cyprus eddy (Zodiatis et al. 2005), that can vary the distribution of pelagic-stage juveniles and thus the number of individuals recruiting to each foraging area (Gaspar et al. 2012, Scott et al. 2014, 2017) or (4) a shift in the ecological conditions within Lake Bardawil so that this site now provides a more suitable foraging resource (El-Bana et al. 2002, Abd Ellah \& Hussein 2009, Nada et al. 2013). To expand on this latter hypothesis, evidence suggests that the reopening and ongoing maintenance of the 2 man-made channels in the western and central part of the lake have significantly reduced salinity levels (1970: 100\%, 2012: 46.1\%) (Abd Ellah \& Hussein 2009, Nada et al. 2013 and references therein) and allowed Cymodocea nodosa, the primary dietary item of the green turtle within the Mediterranean (Cardona 2010), to colonise and now dominate the shallow western basin (ElBana et al. 2002, Abd Ellah \& Hussein 2009). Further corroboration from satellite telemetry indicates that the turtles predominately remain within the beds of $C$. nodosa (Nada et al. 2013) which suggests that they might not forage on the Ruppia Cirrhosa that forms monospecific habitats within the eastern basin, and the only seagrass recorded within the lake prior to the reopening of the channels in 1988 (Lipkin 1977, ElBana et al. 2002, Abd Ellah \& Hussein 2009). Therefore, Lake Bardawil might provide a new foraging location as high salinity levels and inadequate forage may have previously precluded green turtles from this site.

The knowledge that a high proportion of recruits are originating from a single site is a critical development in our understanding of foraging area dynamics. At present, the conservation efforts undertaken on the beaches of northern Cyprus have been effective in increasing the number of hatchlings reaching the water (Stokes et al. 2014) with a possible rise in the number of juveniles reaching a reproductive age. However, ensuring that the current trends in recruitment continue may largely depend on the adequate protection of the turtles foraging within Lake Bardawil, although this might be challenging as some humanturtle conflict has been reported as turtle abundance increases (Nada et al. 2013). Therefore, stakeholder discussions and international co-operation are necessary to protect turtles foraging in Egypt in addition to those from the key recognised sites in Libya, namely the Gulf of Bomba and the Gulf of Sirte (Casale 2011, Stokes et al. 2015, Casale \& Heppell 2016).

\section{CONCLUSIONS}

Through the analysis of stable isotopes calibrated by satellite telemetry, we have answered several important questions for the conservation of marine turtles (see Hamann et al. 2010, Rees et al. 2016). These include identifying and assessing the relative 
importance of all major foraging sites utilised by green turtles nesting at Alagadi, quantifying foraging site fidelity and gaining a critical insight into foraging area dynamics.

This work builds upon a detailed, long-term monitoring programme following a marked population (e.g. Broderick et al. 2001, 2003, Stokes et al. 2014, 2015) that emphasises the true value that such individual-based data can provide. The long-term nesting data used to evaluate the annual contributions to the rookery from each foraging area for $>2$ decades was pivotal in identifying the substantial increase in the number of turtles that forage in Lake Bardawil. In turn, this insight emphasises the importance of Cymodocea nodosa for this species and the necessity of protecting these scarce habitats to ensure the long-term viability of green turtles within the Mediterranean.

We stress the importance of having a balanced satellite telemetry campaign, supported by long-term SIA, as contributions from foraging areas to the breeding cohort are unequal among years, and importantly, these proportions can shift dynamically over time. These data can provide essential baseline evidence to advise and monitor marine conservation efforts such as establishing marine protected areas, formulating site-specific management plans and increasing international cooperation through the identification of important migratory links. A caveat to this type of foraging area assessment is that males are poorly represented. Evidence suggests that some foraging areas can be highly female biased, reflecting primary sex ratios (Jensen et al. 2016), and targeted efforts are needed to collect more tissue samples from males. Future research will evaluate the reasons for the substantial shift in the relative importance of these foraging areas and the root cause(s) for the increase in recruitment from Lake Bardawil.

Acknowledgements. P.J.B. is funded by a National Environment Research Council grant 1353865. C.C. is supported by the project CTM2013-48163 from Ministerio de Economía y Competitividad. We thank the following for their support: Marine Turtle Conservation Project (MTCP), Mediterranean Association to Save the Sea Turtles (MEDASSSET), North Cyprus Department of Environmental Protection, seaturtle. org, Society for the Protection of Sea Turtles in North Cyprus (SPOT); and for funding: Apache, British Chelonia Group, BP Egypt, the British High Commission and British Residents Society of North Cyprus, Darwin Initiative, Erwin Warth Foundation, Friends of SPOT, INNPA, Kuzey Kıbrıs Turkcell, NERC, Marine Conservation Society Sea Turtle Conservation Fund, and MEDASSET, UK. We also wish to thank E. Duncan and L. Omeyer and the numerous MTCP volunteers for their tireless efforts during fieldwork. Finally, we thank the editor and 4 anonymous reviewers for their insightful comments that have significantly improved this manuscript.

\section{LITERATURE CITED}

Abd Ellah RG, Hussein MM (2009) Physical limnology of Bardawil Lagoon, Egypt. Am J Agric Environ Sci 5:331-336

Barros NB, Ostrom PH, Stricker CA, Wells RS (2010) Stable isotopes differentiate bottlenose dolphins off west-central Florida. Mar Mamm Sci 26:324-336

* Barrow LM, Bjorndal KA, Reich KJ (2008) Effects of preservation method on stable carbon and nitrogen isotope values. Physiol Biochem Zool 81:688-693

Bjorndal KA, Parsons J, Mustin W, Bolten AB (2013) Threshold to maturity in a long-lived reptile: interactions of age, size, and growth. Mar Biol 160:607-616

Block BA, Jonsen ID, Jorgensen SJ, Winship AJ and others (2011) Tracking apex marine predator movements in a dynamic ocean. Nature 475:86-90

* Bolker BM, Okuyama T, Bjorndal KA, Bolten AB (2007) Incorporating multiple mixed stocks in mixed stock analysis: 'many-to-many' analyses. Mol Ecol 16:685-695

* Bolten AB, Bjorndal KA, Martins HR, Dellinger T, Biscoito MJ, Encalada SE, Bowen BW (1998) Transatlantic developmental migrations of loggerhead sea turtles demonstrated by mtDNA sequence analysis. Ecol Appl 8:1-7

Bond AL, Hobson KA (2012) Reporting stable-isotope ratios in ecology: recommended terminology, guidelines and best practices. Waterbirds 35:324-331

* Bonfil R, Meÿer M, Scholl MC, Johnson R and others (2005) Transoceanic migration, spatial dynamics, and population linkages of white sharks. Science 310:100-103

* Broderick AC, Godley BJ, Hays GC (2001) Trophic status drives interannual variability in nesting numbers of marine turtles. Proc R Soc B 268:1481-1487

* Broderick AC, Glen F, Godley BJ, Hays GC (2003) Variation in reproductive output of marine turtles. J Exp Mar Biol Ecol 288:95-109

* Broderick AC, Coyne MS, Fuller WJ, Glen F, Godley BJ (2007) Fidelity and over-wintering of sea turtles. Proc R Soc B 274:1533-1538

* Cardona L, Aguilar A, Pazos L (2009) Delayed ontogenic dietary shift and high levels of omnivory in green turtles (Chelonia mydas) from the NW coast of Africa. Mar Biol 156:1487-1495

Cardona L, Campos P, Levy Y, Demetropoulos A, Margaritoulis D (2010) Asynchrony between dietary and nutritional shifts during the ontogeny of green turtles (Chelonia mydas) in the Mediterranean. J Exp Mar Bio Ecol 393:83-89

Casale P (2011) Sea turtle by-catch in the Mediterranean. Fish Fish 12:299-316

* Casale P, Heppell S (2016) How much sea turtle bycatch is too much? A stationary age distribution model for simulating population abundance and potential biological removal in the Mediterranean. Endang Species Res 29: $239-254$

* Ceriani SA, Roth JD, Evans DR, Weishampel JF, Ehrhart LM (2012) Inferring foraging areas of nesting loggerhead turtles using satellite telemetry and stable isotopes. PLOS ONE 7:e45335

Ceriani SA, Roth JD, Ehrhart LM, Quintana-Ascencio PF, Weishampel JF (2014) Developing a common currency for stable isotope analyses of nesting marine turtles. Mar Biol 161:2257-2268

* Christiansen F, Esteban N, Mortimer JA, Dujon AM, Hays GC (2017) Diel and seasonal patterns in activity and home range size of green turtles on their foraging grounds 
revealed by extended Fastloc-GPS tracking. Mar Biol 164: $1-11$

Connolly RM, Guest MA, Melville AJ, Oakes JM (2004) Sulfur stable isotopes separate producers in marine foodweb analysis. Oecologia 138:161-167

DeNiro MJ, Epstein S (1978) Influence of diet on the distribution of carbon isotopes in animals. Geochim Cosmochim Acta 42:495-506

* DeNiro MJ, Epstein S (1981) Influence of diet on the distribution of nitrogen isotopes in animals. Geochim Cosmochim Acta 45:341-351

El-Bana M, Khedr A, Van Hecke P, Bogaert J (2002) Vegetation composition of a threatened hypersaline lake (Lake Bardawil), North Sinai. Plant Ecol 163:63-75

Fry B, Scalan RS, Winters JK, Parker PL (1982) Sulphur uptake by salt grasses, mangroves, and seagrasses in anaerobic sediments. Geochim Cosmochim Acta 46: $1121-1124$

Gaspar P, Benson SR, Dutton PH, Réveillère A and others (2012) Oceanic dispersal of juvenile leatherback turtles: going beyond passive drift modeling. Mar Ecol Prog Ser 457:265-284

* Godley BJ, Thompson DR, Waldron S, Furness RW (1998) The trophic status of marine turtles as determined by stable isotope analysis. Mar Ecol Prog Ser 166:277-284

Godley BJ, Richardson S, Broderick AC (2002) Long-term satellite telemetry of the movements and habitat utilisation by green turtles in the Mediterranean. Ecography 25:352-362

Godley BJ, Blumenthal JM, Broderick AC, Coyne MS, Godfrey MH, Hawkes LA, Witt MJ (2008) Satellite tracking of sea turtles: Where have we been and where do we go next? Endang Species Res 4:3-22

Graham BS, Koch PL, Newsome SD, McMahon KW, Aurioles D (2010) Using isocapes to trace the movements and foraging behavior of top predators in oceanic ecosystems. In: West JB, Bowen GJ, Dawson TE, Tu KP (eds) Isoscapes: understanding movement, pattern and process on Earth through isotope mapping. Springer, New York, NY, p 299-318

* Greenwood PJ (1980) Mating systems, philopatry and dispersal in birds and mammals. Anim Behav 28:1140-1162

*Hamann M, Godfrey MH, Seminoff JA, Arthur K and others (2010) Global research priorities for sea turtles: informing management and conservation in the 21st century. Endang Species Res 11:245-269

* Hart KM, Hyrenbach KD (2009) Satellite telemetry of marine megavertebrates: the coming of age of an experimental science. Endang Species Res 10:9-20

* Heide-Jørgensen MP, Laidre KL (2006) Dissolving stock discreteness with satellite tracking: bowhead whales in Baffin Bay. Mar Mamm Sci 22:34-45

Hobson KA (1999) Tracing origins and migration of wildlife using stable isotopes: a review. Oecologia 120:314-326

Hobson KA (2007) Isotopic tracking of migrant wildlife. In: Michener R, Lajtha K (eds) Stable isotopes in ecology and environmental science, 2nd edn. Springer-Blackwell, Oxford, p 155-175

Hobson KA, Schell DM (1998) Stable carbon and nitrogen isotope patterns in baleen from eastern Arctic bowhead whales (Balaena mysticetus). Can J Fish Aquat Sci 55: 2601-2607

Hobson K, Welch H (1992) Determination of trophic relationships within a high Arctic marine food web using $\delta^{13} \mathrm{C}$ and $\delta^{15} \mathrm{~N}$ analysis. Mar Ecol Prog Ser 84:9-18
Hobson KA, Gloutney ML, Gibbs LH (1997) Preservation of blood and tissue samples for stable-carbon and stablenitrogen isotope analysis. Can J Zool 75:1720-1723

Hobson KA, Barnett-Johnson R, Cerling TE (2010) Using isoscapes to track animal migration. In: West JB, Bowen GJ, Dawson TE, Tu KP (eds) Isoscapes: understanding movement, pattern and process on Earth through isotope mapping. Springer, New York, NY, p 273-318

Jaeger A, Lecomte VJ, Weimerskirch H, Richard P, Cherel Y (2010) Seabird satellite tracking validates the use of latitudinal isoscapes to depict predators' foraging areas in the Southern Ocean. Rapid Commun Mass Spectrom 24: 3456-3460

Jeffers VF, Godley BJ (2016) Satellite tracking in sea turtles: How do we find our way to the conservation dividends? Biol Conserv 199:172-184

* Jensen MP, Pilcher N, FitzSimmons NN (2016) Genetic markers provide insight on origins of immature green turtles Chelonia mydas with biased sex ratios at foraging grounds in Sabah, Malaysia. Endang Species Res 31:191-201

Kaufman TJ, Pajuelo M, Bjorndal KA, Bolten AB, Pfaller JB, Williams KL, Vander Zanden HB (2014) Mother-egg stable isotope conversions and effects of lipid extraction and ethanol preservation on loggerhead eggs. Conserv Physiol 2:cou049

Kendall C, Elliott EM, Wankel SD (2007) Tracing anthropogenic inputs of nitrogen to ecosystems. In: Michener R, Lajtha K (eds) Stable isotopes in ecology and environmental science, 2nd edn. Springer-Blackwell, Oxford, p 375-449

Koch PL (2007) Isotopic study of biology of modern and fossil vertebrates. In: Micherner R, Lajtha K (eds) Stable isotopes in ecology and environmental science, 2nd edn. Springer-Blackwell, Oxford, p 99-154

Lipkin Y (1977) Seagrass vegetation of Sinai and Israel. In: McRoy CP, Helfferich C (eds) Seagrass ecosystems: a scientific perspective. Marcel Dekker, New York, NY, p 263-293

*McMahon KW, Hamady LL, Thorrold SR (2013) A review of ecogeochemistry approaches to estimating movements of marine animals. Limnol Oceanogr 58:697-714

Meylan AB, Bowen BW, Avise JC (1990) A genetic test of the natal homing versus social facilitation models for green turtle migration. Science 248:724-727

Michener RH, Kaufman L (2007) Stable isotope ratios as tracers in marine food webs: an update. In: Michener RH, Lajtha K (eds) Stable isotopes in ecology and environmental science, 2nd edn. Springer-Blackwell, Oxford, p 238-282

Moncreiff C, Sullivan M (2001) Trophic importance of epiphytic algae in subtropical seagrass beds: evidence from multiple stable isotope analyses. Mar Ecol Prog Ser 215: 93-106

Nada M, Boura L, Grimanis K, Schofield G and others (2013) Egypt's Bardawil Lake: safe haven or deadly trap for sea turtles in the Mediterranean. A report by MEDASSET, Athens, Suez Canal University, Ismailia, and Nature Conservation Egypt

Newsome SD, Martinez del Rio C, Bearhop S, Phillips DL (2007) A niche for isotopic ecology. Front Ecol Environ 5: $429-436$

Oakes JM, Connolly RM (2004) Causes of sulfur isotope variability in the seagrass, Zostera capricorni. J Exp Mar Biol Ecol 302:153-164

Pajuelo M, Bjorndal KA, Reich KJ, Vander Zanden HB, 
Hawkes LA, Bolten AB (2012) Assignment of nesting loggerhead turtles to their foraging areas in the Northwest Atlantic using stable isotopes. Ecosphere 3:art89

* Pajuelo M, Bjorndal KA, Arendt MD, Foley AM, Schroeder BA, Witherington BE, Bolten AB (2016) Long-term resource use and foraging specialization in male loggerhead turtles. Mar Biol 163:235

Peterson BJ, Fry B (1987) Stable isotopes in ecosystems studies. Annu Rev Ecol Syst 18:293-320

* Post DM, Layman CA, Arrington DA, Takimoto G, Quattrochi J, Montaña CG (2007) Getting to the fat of the matter: models, methods and assumptions for dealing with lipids in stable isotope analyses. Oecologia 152:179-189

Rees A, Alfaro-Shigueto J, Barata P, Bjorndal K and others (2016) Are we working towards global research priorities for management and conservation of sea turtles? Endang Species Res 31:337-382

Reich KJ, Bjorndal KA, Bolten AB (2007) The 'lost years' of green turtles: using stable isotopes to study cryptic lifestages. Biol Lett 3:712-714

Reich KJ, Bjorndal KA, Martínez Del Rio C (2008) Effects of growth and tissue type on the kinetics of ${ }^{13} \mathrm{C}$ and ${ }^{15} \mathrm{~N}$ incorporation in a rapidly growing ectotherm. Oecologia 155:651-663

* Revuelta O, Hawkes L, León YM, Godley BJ, Raga JA, Tomás J (2015) Evaluating the importance of Marine Protected Areas for the conservation of hawksbill turtles Eretmochelys imbricata nesting in the Dominican Republic. Endang Species Res 27:169-180

Robinson NJ, Morreale SJ, Nel R, Paladino FV (2016) Coastal leatherback turtles reveal conservation hotspot. Sci Rep 6:37851

Royle AJ, Rubenstein DR (2004) The role of species abundance in determining breeding origins of migratory birds with stable isotopes. Ecol Appl 14:1780-1788

Rubenstein DR, Hobson KA (2004) From birds to butterflies: animal movement patterns and stable isotopes. Trends Ecol Evol 19:256-263

Schofield G, Hobson VJ, Fossette S, Lilley MKS, Katselidis KA, Hays GC (2010) Fidelity to foraging sites, consistency of migration routes and habitat modulation of home range by sea turtles. Divers Distrib 16:840-853

Schofield G, Scott R, Dimadi A, Fossette S and others (2013) Evidence-based marine protected area planning for a highly mobile endangered marine vertebrate. Biol Conserv 161:101-109

Scott R, Hodgson DJ, Witt MJ, Coyne MS and others (2012) Global analysis of satellite tracking data shows that adult green turtles are significantly aggregated in Marine Protected Areas. Glob Ecol Biogeogr 21:1053-1061

Scott R, Marsh R, Hays GC (2014) Ontogeny of long distance migration. Ecology 95:2840-2850

Scott R, Biastoch A, Agamboue PD, Bayer T and others (2017) Spatio-temporal variation in ocean current-driven hatchling dispersion: implications for the world' s largest leatherback sea turtle nesting region. Divers Distrib: $1-11$

Seminoff JA, Jones TT, Eguchi T, Jones DR, Dutton PH (2006) Stable isotope discrimination $\left(\delta^{13} \mathrm{C}\right.$ and $\left.\delta^{15} \mathrm{~N}\right)$ between soft tissues of the green sea turtle Chelonia mydas and its diet. Mar Ecol Prog Ser 308:271-278

Seminoff JA, Benson SR, Arthur KE, Eguchi T, Dutton PH, Tapilatu RF, Popp BN (2012) Stable isotope tracking of endangered sea turtles: validation with satellite telemetry and $\delta^{15} \mathrm{~N}$ analysis of amino acids. PLOS ONE 7:e37403
Shillinger GL, Palacios DM, Bailey H, Bograd SJ and others (2008) Persistent leatherback turtle migrations present opportunities for conservation. PLOS Biol 6:e171

* Shimada T, Aoki S, Kameda K, Hazel J, Reich K, Kamezaki N (2014) Site fidelity, ontogenetic shift and diet composition of green turtles Chelonia mydas in Japan inferred from stable isotope analysis. Endang Species Res 25:151-164

Shimada T, Limpus C, Jones R, Hazel J, Groom R, Hamann $M$ (2016) Sea turtles return home after intentional displacement from coastal foraging areas. Mar Biol 163:1-14

Somes CJ, Schmittner A, Galbraith ED, Lehmann MF and others (2010) Simulating the global distribution of nitrogen isotopes in the ocean. Global Biogeochem Cycles 24: $1-16$

* Stokes KL, Fuller WJ, Glen F, Godley BJ, Hodgson DJ, Rhodes KA, Snape RTE (2014) Detecting green shoots of recovery: the importance of long-term individual-based monitoring of marine turtles. Anim Conserv 17:593-602

Stokes KL, Broderick AC, Canbolat AF, Candan O and others (2015) Migratory corridors and foraging hotspots: critical habitats identified for Mediterranean green turtles. Divers Distrib 21:665-674

Thode HG (1991) Sulphur isotopes in nature and the environment: an overview. In: Krouse HR, Grinenko VA (eds) Stable isotopes in the assessment of natural and anthropogenic sulphur in the environment. SCOPE, John Wiley \& Sons, Chichester, p 1-26

Thomson J, Heithaus MR, Burkholder D, Vaudo J, Wirsing A, Dill L (2012) Site specialists, diet generalists? Isotopic variation, site fidelity, and foraging by loggerhead turtles in Shark Bay, Western Australia. Mar Ecol Prog Ser 453: 213-226

Tillberg CV, McCarthy DP, Dolezal AG, Suarez AV (2006) Measuring the trophic ecology of ants using stable isotopes. Insectes Soc 53:65-69

* Tucker A, MacDonald B, Seminoff J (2014) Foraging site fidelity and stable isotope values of loggerhead turtles tracked in the Gulf of Mexico and northwest Caribbean. Mar Ecol Prog Ser 502:267-279

* Vander Zanden MJ, Vadeboncoeur Y, Diebel MW, Jeppesen E (2005) Primary consumer stable nitrogen isotopes as indicators of nutrient source. Environ Sci Technol 39: 7509-7515

*Vander Zanden HB, Bjorndal KA, Reich KJ, Bolten AB (2010) Individual specialists in a generalist population: results from a long-term stable isotope series. Biol Lett 6: 711-714

Vander Zanden HB, Bjorndal KA, Bolten AB (2013) Temporal consistency and individual specialization in resource use by green turtles in successive life stages. Oecologia 173:767-777

*Vander Zanden HB, Tucker AD, Hart KM, Lamont MM and others (2015) Determining origin in a migratory marine vertebrate: a novel method to integrate stable isotopes and satellite tracking. Ecol Appl 25:320-335

*Webster MS, Marra PP, Haig SM, Bensch S, Holmes RT (2002) Links between worlds: unraveling migratory connectivity. Trends Ecol Evol 17:76-83

*Wilson RP, McMahon CR (2006) Measuring devices on wild animals: What constitutes acceptable practice? Front Ecol Environ 4:147-154

Wright LI, Stokes KL, Fuller WJ, Godley BJ and others (2012) Turtle mating patterns buffer against disruptive effects of climate change. Proc Biol Sci 279:2122-2127

*Wunder MB (2012) Determining geographic patterns of 
migration and dispersal using stable isotopes in keratins. J Mammal 93:360-367

Zbinden J, Bearhop S, Bradshaw P, Gill B, Margaritoulis D, Newton J, Godley B (2011) Migratory dichotomy and associated phenotypic variation in marine turtles revealed by satellite tracking and stable isotope analysis. Mar Ecol Prog Ser 421:291-302

Zerbini A, Andriolo A, Heide-Jørgensen MP, Pizzorno JL,

Editorial responsibility: Keith Hobson,

London, Ontario, Canada
Maia Y, VanBlaricom G (2006) Satellite-monitored movements of humpback whales Megaptera novaeangliae in the Southwest Atlantic Ocean. Mar Ecol Prog Ser 313: 295-304

Zodiatis G, Drakopoulos P, Brenner S, Groom S (2005) Variability of the Cyprus warm core eddy during the CYCLOPS project. Deep Sea Res II Top Stud Oceanogr 52:2897-2910

Submitted: February 14, 2017; Accepted: August 3, 2017 Proofs received from author(s): October 22, 2017 